\title{
GMR
}

\section{Association between the expression of HIF-1a and VEGF and prognostic implications in primary liver cancer}

\author{
L.Y. Guo, P. Zhu and X.P. Jin \\ Department of Gastroenterology, \\ First Affiliated Hospital of Liaoning Medical College, Liaoning, China \\ Corresponding author: X.P. Jin \\ E-mail: jinxupeng_11@163.com
}

Genet. Mol. Res. 15 (2): gmr.15028107

Received November 19, 2015

Accepted January 18, 2016

Published May 6, 2016

DOI http://dx.doi.org/10.4238/gmr.15028107

\begin{abstract}
The goal of this study was to investigate the expression of hypoxia-inducible factor-1 $\alpha$ (HIF-1 $\alpha$ ) and vascular endothelial growth factor (VEGF) in primary liver cancer (PLC) and their association with prognosis. Tumor tissue, non-tumor tissue, and blood samples of 75 PLC patients were collected. Blood samples of 20 volunteers were also collected as healthy controls. Realtime quantitative reverse transcription-polymerase chain reaction was used to analyze the mRNA levels of HIF-1 $\alpha$ and VEGF in the tissues. Protein expression of HIF-1 $\alpha$ and VEGF was analyzed by immunohistochemistry. Enzyme-linked immunosorbent assay was used to detect the expression of HIF-1 $\alpha$ and VEGF at the serum level. Univariate tests, multivariate Cox proportional hazards model, and the Student $t$-test were used to analyze the data. HIF-1 $\alpha$ and VEGF showed higher expression in PLC tumor tissue both at the mRNA and protein levels. HIF-1 $\alpha$ and VEGF expression was positive in 62.67 and $66.67 \%$ of PLC patients, respectively. HIF-1 $\alpha$ and VEGF expression was significantly related to tumor stage and lymph nodes and lung metastases $(\mathrm{P}<0.05)$. HIF-1 $\alpha$ expression correlated with
\end{abstract}


VEGF expression in PLC $(\mathrm{r}=0.665, \mathrm{P}<0.05)$. Both HIF-1 $\alpha$ and VEGF were significantly associated with overall survival $(\mathrm{P}<0.05)$, while HIF- $1 \alpha$ was identified as an independent prognostic factor. Both HIF- $1 \alpha$ and VEGF, as the predictors of efficacy of TACE and metastasis of PLC, are biomarkers indicating PLC in advanced stage, and implied poor prognosis in patients with PLC. HIF-1 $\alpha$ and VEGF could potentially be targets to improve outcomes in PLC.

Key words: HIF-1 $\alpha$; VEGF; Primary liver cancer; Prognosis

\section{INTRODUCTION}

Primary liver cancer (PLC) is one of the most common malignancies and the third leading cause of cancer mortality in the world (Parkin et al., 2005). About 560,000 people are diagnosed with PLC and 550,000 die of PLC each year (McGlynn and London, 2005). According to Folkman and Klagsbrun (1987), the solid tumors need neovascularization for their generation and development in order to supply oxygen and nutrition. The tumor microenvironment is hypoxic because of the structural and functional abnormalities of vessels and increasing oxygen consumption due to the proliferation of tumor cells. Hypoxia inducible factor-1 (HIF-1), composed of HIF- $1 \alpha$ and $\beta$, is a heterodimeric protein and has an important role in $\mathrm{O}_{2}$ homeostasis (Wang et al., 1995; Iyer et al., 1998). HIF-1 generally resides in anoxic mammalian cells and has been identified as the critical protein reacting directly to hypoxia (Talks et al., 2000). HIF-1 $\beta$ is constitutively expressed, while HIF-1 $\alpha$ is degraded in the ubiquitin proteasome pathway under normoxic conditions (Salceda and Caro, 1997). Decreased oxygen (hypoxia) is the signal for angiogenesis induction. HIF-1 could activate many hypoxia-induced genes, such as erythropoietin and angiogenic factors. Vascular endothelial growth factor (VEGF) is one of the angiogenic factors regulated by hypoxia (Minet et al., 2000).

Both HIF-1 $\alpha$ and VEGF are important regulators of angiogenesis and have been reported to be expressed in many kinds of cancers. Huang et al. (2005) found that the levels of HIF-1 $\alpha$ and VEGF in tumor tissues are significantly higher than in the adjacent tissues, indicating that HIF-1 $\alpha$ might play an important role in neovascularization in PLC by regulating the transcription of VEGF.

Transcatheter arterial chemoembolization (TACE) is widely accepted as the treatment for PLC, but post-TACE recurrence of PLC and metastasis remains high. Carmeliet and Jain (2000) showed that tumor angiogenesis plays an important role in the recurrence and metastasis of PLC.

Upon early diagnosis, it is helpful to improve the efficacy and clinical outcomes in PLC patients by understanding clinical prognostic factors and performing surgical treatment, including chemotherapy and radiotherapy. In fact, many prognostic factors are still unknown and those already identified are not clearly understood mechanistically. Therefore, additional prognostic biomarkers are needed for the management of PLC. The investigation of the association between tumor biology and clinical features is important to aid with antiangiogenic therapy. The purpose of our study is to investigate the expression of HIF-1 $\alpha$ and VEGF in PLC tumors and their influence on clinical outcomes and prognosis in human PLC. 


\section{MATERIAL AND METHODS}

\section{Patients}

PLC tumor tissue and blood samples were obtained from 75 patients with PLC (47 males and 28 females; aged 30-77; average age, $57.73 \pm 11.06$ ). All patients were hospitalized in the First Affiliated Hospital of Liaoning Medical College from October 2007 to September 2009. Samples of the adjacent tissue ( $5 \mathrm{~cm}$ away from tumor tissue) were taken as negative controls. Blood samples were taken from 20 volunteers in the same hospital and were used as healthy controls. No patients had a history of chemotherapy or radiotherapy before surgery. Informed consent was obtained from all patients. The study involving the tissue samples was approved by the medical Ethics Committee of the First Affiliated Hospital of Liaoning Medical College.

\section{Total RNA isolation and cDNA synthesis}

Fresh PLC tissue samples were obtained after resection. Total RNA was extracted from the tumor tissue and adjacent tissue with TRIzol reagent (Thermo Fisher Scientific Inc., Shanghai, China). Five micrograms of RNA was reverse transcribed to cDNA with the First-Strand cDNA Synthesis Kit (Thermo Fisher Scientific Inc.) according to the manufacturer protocol.

\section{Real-time quantitative reverse transcription-polymerase chain reaction (RT-PCR) assay}

Primers and the TaqMan probes for HIF-1 $\alpha$, VEGF and glyceraldehyde-3-phosphate dehydrogenase (GAPDH) were designed by Invitrogen ${ }^{\mathrm{TM}}$ (Thermo Fisher Scientific Inc.). The sequences of primers and TaqMan probes are shown in Table 1. The reaction was carried on with One-Step RT-PCR System (Thermo Fisher Scientific Inc.) according to the manufacturer instructions. The PCR conditions were: $2 \mathrm{~min}$ at $50^{\circ} \mathrm{C}, 30 \mathrm{~s}$ at $95^{\circ} \mathrm{C}, 30 \mathrm{~s}$ at $65^{\circ} \mathrm{C}$ with 40 cycles, and then $1 \mathrm{~min}$ at $60^{\circ} \mathrm{C}$. PCRs and subsequent calculations were performed with QuantStudio $^{\mathrm{TM}} 3$ and QuantStudio ${ }^{\mathrm{TM}} 5$ (Thermo Fisher Scientific Inc.).

\begin{tabular}{|c|c|}
\hline Gene & Sequence \\
\hline \multirow[t]{3}{*}{ HIF-1 $1 \alpha$} & F: 5'-CATAAAGTCTGCAACATGGAAGGT-3' \\
\hline & R: 5'-ATTTGATGGGTGAGGAATGGGTT-3' \\
\hline & TaqMan probe: 5'-CCTGTGCAGTGCAATACCTTCCATGTTG-3' \\
\hline \multirow[t]{3}{*}{ VEGF } & F: 5'-AGGAGGAGGGCAGAATCATCA-3' \\
\hline & R: 5'-TCTCGATTGGATGGCAGTAGC-3' \\
\hline & TaqMan probe: 5'-TGGTGAAGTTCATGGATGTCTATCAGCGC-3' \\
\hline \multirow[t]{3}{*}{ GAPDH } & F: 5'-GAAGGTGAAGGTCGGAGTC-3' \\
\hline & R: 5'-GAAGATGGTGATGGGATTTC-3' \\
\hline & TaqMan probe: 5'-CAAGCTTCCCGTTCTCAGCC-3' \\
\hline
\end{tabular}

$\mathrm{F}=$ forward primer; $\mathrm{R}=$ reverse primer.

\section{Histology}

All 75 patients were diagnosed with PLC according to standards of the Chinese Society of Liver Cancer (CSLC) and previous research (Kew et al., 1971). Fresh PLC samples were 
received after resection. Samples were fixed in $10 \% \mathrm{pH}$-neutral formalin (Solarbio Technology Co., Ltd., Beijing, China) and then embedded in paraffin (Solarbio Technology Co., Ltd.). The histological slides were reviewed and diagnosed by two pathologists with more than 20 years of experience to evaluate the patterns and intensity of HIF- $1 \alpha$ and VEGF reactivity.

\section{Immunohistochemistry}

The process of immunohistochemistry was performed with the EnVision method (Kämmerer et al., 2001) and relative specifications of the reagents. The fixed and embedded tissues were cut into tubes of $15 \times 15 \times 5 \mathrm{~mm}$. Five micrometers of the sections were consecutively cut from the tubes. The sections were mounted on silanized slides and dried at $37^{\circ} \mathrm{C}$ overnight. After deparaffinization with gradient ethanol and rehydratation, the slides were incubated with $3 \%$ hydrogen peroxide solution for $5 \mathrm{~min}$, then repaired with ethylenediaminetetraacetic acid for $40 \mathrm{~min}$. The rabbit anti HIF-1 $\alpha$ (1:100) and VEGF (1:100) polyclonal primary antibodies (Proteintech Group Inc., Wuhan, China) were incubated with the slides at $37^{\circ} \mathrm{C}$ for $60 \mathrm{~min}$ then at $4^{\circ} \mathrm{C}$ overnight. The slides were incubated with secondary goat anti-rabbit polyclonal antibody (1:1000; Jackson Immuno Research Labotatories, Inc., Shanghai, China) labeled with horseradish peroxidase at room temperature for $1 \mathrm{~h}$. The slides were visualized with Pierce ${ }^{\mathrm{TM}}$ DAB Substrate Kit (Thermo Fisher Scientific Inc.) according to the manufacturer instructions.

\section{Scoring criteria}

In total, five random fields of vision were observed under microscope (400X) (Thermo Fisher Scientific Inc.). Two hundred cells were counted per field and the percentage of positive cells was calculated. According to previous research (Zhong et al., 1999), HIF-1 $\alpha$ slides were scored based on whether there was $(+1)$ or was not $(0)$ staining of the nucleus and cytoplasm. The positive expression was dependent on the staining.

The VEGF expression was evaluated according to the extent of staining with the scoring method as follows: 0 (without staining); 1 (less than 10\% staining); 2 (11-50\% staining); and 3 (more than 50\% staining).

The patients were divided into two groups according to the scores: group A (negative) with a score of 0 to 1 and group B (positive) with scores of 2 to 3 (Shibusa et al., 1998).

\section{Serum levels of HIF-1 $\alpha$ and VEGF}

Serum samples were obtained from the 75 patients before TACE and the 20 volunteers. The blood was collected with venous sampling, centrifuged at $1500 \mathrm{~g}$ for $15 \mathrm{~min}$, and stored at $-80^{\circ} \mathrm{C}$. Enzyme-linked immunosorbent assay (ELISA) kits (Human HIF-1 $\alpha$ and VEGF; Takara Biotechnology Co., Ltd., Dalian, China) were used to measure the expression levels in serum. The absorbance values were measured at $450 \mathrm{~nm}$ against the standard curves according to the manufacturer instructions. The average value was calculated from three separate measurements.

\section{Statistical analysis}

All the data were analyzed with the SPSS 11.0 software (Chicago, IL, USA). The 
expression of HIF-1 $\alpha$ and VEGF are reported as means \pm standard deviation (means \pm SD) and compared between tumor and adjacent tissues at the mRNA level by the Student $t$-test. Comparison between patients with PLC and volunteers was done based on serum level. Chisquare analysis was used to analyze the scoring differences between group A and group B of HIF-1 $\alpha$ and VEGF. Kaplan-Meier method and log-rank test were used to assess and compare the impact of HIF-1 $\alpha$ and VEGF expression on survival. Cox regression was used to analyze the effect of HIF-1 $\alpha$ and VEGF expression on survival. Spearman correlation from ranks was used to analyze the interaction between HIF-1 $\alpha$ and VEGF expression. P $<0.05$ was considered statistically significant.

\section{RESULTS}

\section{mRNA levels of HIF-1 $\alpha$ and VEGF}

The mRNA levels of HIF-1 $\alpha$ and VEGF were significantly higher in the tumor tissues of the patients with PLC than the adjacent non-tumor tissues $(\mathrm{P}<0.05)$. The average gray values, meaning the ratio of HIF- $1 \alpha$ and VEGF to GAPDH, are shown in Table 2.

Table 2. mRNA levels of HIF-1 $\alpha$ and VEGF in PLC tumor and the adjacent tissues (means \pm SD).

\begin{tabular}{l|c|c|c}
\hline & Cases $(\mathrm{N})$ & \multicolumn{2}{|c}{ Ratio of gray value } \\
\cline { 3 - 4 } & & HIF-1 $\alpha / \mathrm{GAPDH}$ & $\mathrm{VEGF} / \mathrm{GAPDH}$ \\
\hline Tumor tissue & 75 & $0.93 \pm 1.88$ & $0.81 \pm 1.61$ \\
\hline Adjacent tissue & 75 & $0.37 \pm 1.40^{*}$ & $0.20 \pm 2.56^{*}$ \\
\hline
\end{tabular}

*Compared to tumor tissue, $\mathrm{P}<0.05$.

\section{Protein expression of HIF-1 $\alpha$ and VEGF at the serum level}

The protein expression of HIF-1 $\alpha$ and VEGF at the serum level was significantly higher in the patients with PLC compared to the healthy volunteers $(\mathrm{P}<0.05)$. The average values are shown in Table 3.

Table 3. Protein expression of HIF-1 $\alpha$ and VEGF in serum in patients with PLC and volunteers (means \pm SD).

\begin{tabular}{l|c|c|c}
\hline & Cases $(\mathrm{N})$ & HIF-1 $\alpha(\mathrm{pg} / \mathrm{mL})$ & VEGF $(\mathrm{pg} / \mathrm{mL})$ \\
\hline PLC patients & 75 & $160.61 \pm 69.4$ & $271.98 \pm 150.12$ \\
\hline Healthy volunteers & 20 & $22.99 \pm 9.10^{*}$ & $73.12 \pm 25.88^{*}$ \\
\hline
\end{tabular}

*Compared to tumor tissue, $\mathrm{P}<0.05$.

\section{Expression of HIF-1 $\alpha$ and VEGF in PLC tumor tissue and the adjacent non-tumor tissues}

There were 47 PLC patients with positive HIF-1 $\alpha$ staining (62.67\%), which expressed strongly in the epithelium and necrotic tumor tissue. VEGF was positive in 50 tumor samples from the PLC patients (66.67\%), with expression seen in some of the adjacent tissue as well. 


\section{Association of HIF-1 $\alpha$ and VEGF with clinical outcomes}

There were no significant associations of HIF-1 $\alpha$ and VEGF expression with the clinical parameters, including gender, age, tumor size, histological differentiation degree, or invasive depth (Table 4). However, the expression differences of HIF-1 $\alpha$ and VEGF were significantly related to tumor stage (especially in stage III) and lymph nodes and lung metastases $(\mathrm{P}<0.05$; Table 5).

\section{Table 4. Association between HIF-1 $\alpha$ and clinical parameters.}

\begin{tabular}{|c|c|c|c|c|c|}
\hline \multicolumn{2}{|l|}{ Factors } & \multirow{4}{*}{$\begin{array}{c}\text { Cases (N) } \\
21 \\
54\end{array}$} & \multicolumn{3}{|c|}{ HIF- $1 \alpha$} \\
\hline & & & \multirow{2}{*}{$\begin{array}{c}\text { Positive expression } \\
14(66.7 \%) \\
\end{array}$} & \multirow{3}{*}{$\begin{array}{c}\chi^{2} \\
0.781\end{array}$} & \multirow{3}{*}{$\begin{array}{c}\mathrm{P} \text { value } \\
0.334\end{array}$} \\
\hline \multirow[t]{2}{*}{ Gender } & $<60$ & & & & \\
\hline & $\geq 60$ & & $33(61.1 \%)$ & & \\
\hline \multirow[t]{2}{*}{ Sex } & Male & 49 & $32(65.3 \%)$ & \multirow[t]{2}{*}{0.098} & \multirow[t]{2}{*}{0.886} \\
\hline & Female & 26 & $15(57.7 \%)$ & & \\
\hline \multirow[t]{2}{*}{ Tumor size } & $<5 \mathrm{~cm}$ & 35 & $20(57.1 \%)$ & \multirow{2}{*}{0.002} & \multirow{2}{*}{0.592} \\
\hline & $\geq 5 \mathrm{~cm}$ & 40 & $27(67.5 \%)$ & & \\
\hline \multirow[t]{3}{*}{ Differentiation grade } & Poor & 15 & $6(40.0 \%)$ & \multirow[t]{3}{*}{3.005} & \multirow[t]{3}{*}{0.760} \\
\hline & Moderate & 52 & $35(67.3 \%)$ & & \\
\hline & Well & 8 & $6(75.0 \%)$ & & \\
\hline \multirow[t]{2}{*}{ Invasion depth } & $\mathrm{T} 1+\mathrm{T} 2$ & 16 & $10(62.5 \%)$ & \multirow[t]{2}{*}{0.133} & \multirow[t]{2}{*}{0.453} \\
\hline & $\mathrm{T} 3+\mathrm{T} 4$ & 59 & $37(62.7 \%)$ & & \\
\hline \multirow[t]{2}{*}{ Tumor stage } & I, II & 48 & $25(52.1 \%)$ & \multirow[t]{2}{*}{13.676} & \multirow[t]{2}{*}{0.001} \\
\hline & III & 27 & $22(81.2 \%)$ & & \\
\hline \multirow[t]{2}{*}{ Lymph node metastasis } & Yes & 33 & $24(72.7 \%)$ & \multirow[t]{2}{*}{12.902} & \multirow[t]{2}{*}{0.002} \\
\hline & No & 42 & $23(54.8 \%)$ & & \\
\hline \multirow[t]{2}{*}{ Lung metastasis } & Yes & 10 & $9(90.0 \%)$ & \multirow[t]{2}{*}{7.003} & \multirow[t]{2}{*}{0.010} \\
\hline & No & 65 & $38(58.5 \%)$ & & \\
\hline
\end{tabular}

Table 5. Association between VEGF and clinical parameters.

\begin{tabular}{|c|c|c|c|c|c|}
\hline \multicolumn{2}{|l|}{ Factors } & \multirow{4}{*}{$\begin{array}{c}\text { Cases (N) } \\
21 \\
54\end{array}$} & \multicolumn{3}{|c|}{ VEGF } \\
\hline & & & \multirow{2}{*}{\begin{tabular}{|c|} 
Positive expression \\
$14(66.7 \%)$ \\
\end{tabular}} & \multirow{3}{*}{$\begin{array}{c}\chi^{2} \\
0.045\end{array}$} & \multirow{3}{*}{$\frac{P \text { value }}{0.938}$} \\
\hline \multirow[t]{2}{*}{ Age } & $<60$ & & & & \\
\hline & $\geq 60$ & & $36(66.7 \%)$ & & \\
\hline \multirow[t]{2}{*}{ Gender } & Male & 49 & $31(63.3 \%)$ & \multirow[t]{2}{*}{0.143} & \multirow[t]{2}{*}{0.760} \\
\hline & Female & 26 & $19(73.0 \%)$ & & \\
\hline \multirow[t]{2}{*}{ Tumor size } & $<5 \mathrm{~cm}$ & 35 & $24(68.6 \%)$ & \multirow[t]{2}{*}{0.606} & \multirow[t]{2}{*}{0.588} \\
\hline & $\geq 5 \mathrm{~cm}$ & 40 & $26(65.0 \%)$ & & \\
\hline \multirow[t]{3}{*}{ Differentiation grade } & Poor & 15 & $6(40.0 \%)$ & \multirow[t]{3}{*}{4.998} & \multirow[t]{3}{*}{0.095} \\
\hline & Moderate & 52 & $37(71.2 \%)$ & & \\
\hline & Well & 8 & $7(87.5 \%)$ & & \\
\hline \multirow[t]{2}{*}{ Invasion depth } & $\mathrm{T} 1+\mathrm{T} 2$ & 16 & $10(62.5 \%)$ & \multirow[t]{2}{*}{0.175} & \multirow[t]{2}{*}{0.430} \\
\hline & $\mathrm{T} 3+\mathrm{T} 4$ & 59 & $40(67.8 \%)$ & & \\
\hline \multirow[t]{2}{*}{ Tumor stage } & I, II & 48 & $27(56.3 \%)$ & \multirow[t]{2}{*}{30.641} & \multirow[t]{2}{*}{0.010} \\
\hline & III & 27 & $23(85.2 \%)$ & & \\
\hline \multirow[t]{2}{*}{ Lymph node metastasis } & Yes & 33 & $28(84.8 \%)$ & \multirow[t]{2}{*}{30.002} & \multirow[t]{2}{*}{0.009} \\
\hline & No & 42 & $22(52.4 \%)$ & & \\
\hline \multirow[t]{2}{*}{ Lung metastasis } & Yes & 10 & $9(90.0 \%)$ & \multirow[t]{2}{*}{7.980} & \multirow[t]{2}{*}{0.015} \\
\hline & No & 65 & $41(63.1 \%)$ & & \\
\hline
\end{tabular}

\section{Association of HIF-1 $\alpha$ and VEGF expression with prognosis}

According to the results of univariate prognostic analysis after following up with patients for 6 years, 40 of the 75 PLC patients were alive while 35 passed away during the follow-up. The overall survival (OS) in 6 years for the 75 patients was 53.3\%. The 
OS for patients with positive and negative HIF-1 $\alpha$ was $42.6 \%$ (20/47) and 71.4\% (20/28), respectively, which indicated that positive HIF-1 $\alpha$ resulted in poorer prognosis $(\mathrm{P}<0.05)$. HIF- $1 \alpha$ expression was negatively related to the survival time in patients with $\operatorname{PLC}(\mathrm{P}<0.05$; log-rank test).

The OS for PLC patients with positive and negative VEGF was 42.0\% (21/50) and $76.0 \%(19 / 25)$, respectively, which indicated that positive VEGF resulted in shorter survival time $(\mathrm{P}<0.05)$. VEGF expression was negatively related to the survival time in patients with PLC $(\mathrm{P}<0.05$; log-rank test).

According to the results of multivariate analysis and Cox's proportional hazard model, HIF-1 $\alpha$ expression was related to the OS $(\mathrm{P}<0.05$, relative risk $=2.33)$, while VEGF expression was not related to the OS. Multivariate analysis indicated that HIF-1 $\alpha$ expression was the independent prognostic factor for OS of patients with PLC.

\section{Association between HIF-1 $\alpha$ and VEGF in PLC patients}

There were 47 patients with positive HIF-1 $\alpha$ expression and 50 patients with positive VEGF expression, while 28 patients were negative for HIF- $\alpha$ expression and 25 patients were negative for VEGF expression. With Spearman analysis, there was a positive correlation between HIF- $1 \alpha$ and VEGF $(r=0.665, \mathrm{P}<0.05)$ in patients with PLC.

\section{DISCUSSION}

The main findings in our study were that the expression of HIF-1 $\alpha$ and VEGF were higher at both an mRNA and protein level in patients with PLC. HIF-1 $\alpha$ and VEGF expression were associated with advanced tumor stage and implied poor prognosis in patients with PLC. HIF-1 $\alpha$ was an independent prognostic factor for OS of patients with PLC.

In previous studies, HIF-1 and VEGF were found to be important regulators in angiogenesis (Forsythe et al., 1996). HIF-1 is a heterodimer composed of HIF- $1 \alpha$ and HIF-1 $\beta$ subunits, belonging to the basic-loop-helix-Per-Arnt-Sim (PAS) protein family of transcription factors. HIF- $1 \alpha$ has a critical role in maintaining the energy metabolism, angiogenesis, proliferation, and metastasis of tumor cells (Rankin and Giaccia, 2008), and has a significant impact on survival in colorectal cancers and lung metastasis (Rajaganeshan et al., 2009). HIF$1 \alpha$ can activate the expression of $V E G F$ by binding to the hormone-response element in the promoter region of VEGF (Semenza, 2000). HIF-1 $\alpha$ is a hexose-modified multifunctional protein (Houck et al., 1991) and acts on vascular endothelial cells (Guba et al., 2002), leading to hyperplasia in tumor vessels and resulting in tumor development (Liao and Johnson, 2007).

In our study, the HIF-1 $\alpha$ and VEGF expression increased both at the mRNA and protein levels in patients with PLC compared to the controls. This phenomenon indicates that during tumor generation and development, the tumor tissue grows faster than angiogenesis occurs, leading to hypoxia. This induces the overexpression of HIF-1 $\alpha$ and VEGF to promote vessel formation, providing tumors with oxygen and nutrients.

The major purpose of our research was to evaluate the impact of HIF-1 $\alpha$ and VEGF expression on prognosis in patients with PLC and investigate the association of the two with clinical parameters. We found that HIF-1 $\alpha$ was positive in 47 of the 75 patients with PLC, while VEGF was positive in 50 of 75. Both HIF-1 $\alpha$ and VEGF had higher expression in tumor 
tissue compared to non-tumor tissue, which is in accordance with previous studies (Zagzag et al., 2000; Bos et al., 2003; Jiang et al., 2003). HIF-1 $\alpha$ was found to be associated with differentiation stage and lymph nodes and lung metastases, as also shown by Kurokawa et al. (2003) and Maxwell et al. (1997), but were not associated with age, gender, tumor size, degree of histological differentiation, or invasion depth. Overexpression of HIF-1 $\alpha$ and VEGF were found in stage III tumors and lymph nodes and lung metastasis, confirming that HIF-1 $\alpha$ and VEGF could be biomarkers indicating tumor invasion and metastasis in PLC.

Additionally, our results showed that the 6-year OS of the patients with positive and negative HIF-1 $\alpha$ expression was $42.6 \%$ (20/47) and 71.4\% (20/28), respectively. The patients with positive HIF-1 $\alpha$ expression had poorer prognosis compared to those with negative HIF$1 \alpha$ expression. The 6-year OS of the patients with positive and negative VEGF expression was $42.0 \%(21 / 50)$ and $76.0 \%(19 / 25)$, respectively. The patients with positive VEGF expression had poorer prognosis compared to those with negative VEGF expression. As a result, the positive expression of both HIF- $1 \alpha$ and VEGF implied poor prognosis.

Analyzed by multivariate Cox, HIF-1 $\alpha$ was the independent prognostic variable for OS of patients with PLC, while VEGF was not but was shown to be a risk factor for mortality. According to Wang et al. (2009), there was a significant positive correlation between HIF-1 $\alpha$ and VEGF expression, and both were important in tumor generation and development. In our study, we also found that HIF-1 $\alpha$ was positively correlated to VEGF both at mRNA and protein levels.

However, there were still some defects in our study such as the small sample size. We still need further studies to prove the impact of HIF-1 $\alpha$ and VEGF expression on prognosis. In conclusion, HIF-1 $\alpha$ and VEGF may be biomarkers indicating tumor invasion and poor prognosis in human PLC. Both HIF-1 $\alpha$ and VEGF could potentially be therapeutic targets in treating PLC.

\section{Conflicts of interest}

The authors declare no conflict of interest.

\section{REFERENCES}

Bos R, van der Groep P, Greijer AE, Shvarts A, et al. (2003). Levels of hypoxia-inducible factor-1alpha independently predict prognosis in patients with lymph node negative breast carcinoma. Cancer 97: 1573-1581. http://dx.doi. org $/ 10.1002 /$ cncr. 11246

Carmeliet P and Jain RK (2000). Angiogenesis in cancer and other diseases. Nature 407: 249-257. http://dx.doi. org $/ 10.1038 / 35025220$

Folkman J and Klagsbrun M (1987). Angiogenic factors. Science 235: 442-447. http://dx.doi.org/10.1126/science.2432664

Forsythe JA, Jiang BH, Iyer NV, Agani F, et al. (1996). Activation of vascular endothelial growth factor gene transcription by hypoxia-inducible factor 1. Mol. Cell. Biol. 16: 4604-4613. http://dx.doi.org/10.1128/MCB.16.9.4604

Guba M, von Breitenbuch P, Steinbauer M, Koehl G, et al. (2002). Rapamycin inhibits primary and metastatic tumor growth by antiangiogenesis: involvement of vascular endothelial growth factor. Nat. Med. 8: 128-135. http://dx.doi. org/10.1038/nm0202-128

Houck KA, Ferrara N, Winer J, Cachianes G, et al. (1991). The vascular endothelial growth factor family: identification of a fourth molecular species and characterization of alternative splicing of RNA. Mol. Endocrinol. 5: 1806-1814. http://dx.doi.org/10.1210/mend-5-12-1806

Huang GW, Yang LY and Lu WQ (2005). Expression of hypoxia-inducible factor 1alpha and vascular endothelial growth factor in hepatocellular carcinoma: Impact on neovascularization and survival. World J. Gastroenterol. 11: 17051708. http://dx.doi.org/10.3748/wjg.v11.i11.1705

Iyer NV, Kotch LE, Agani F, Leung SW, et al. (1998). Cellular and developmental control of O2 homeostasis by hypoxiainducible factor 1 alpha. Genes Dev. 12: 149-162. http://dx.doi.org/10.1101/gad.12.2.149 
Jiang YA, Fan LF, Jiang CQ, Zhang YY, et al. (2003). Expression and significance of PTEN, hypoxia-inducible factor-1 alpha in colorectal adenoma and adenocarcinoma. World J. Gastroenterol. 9: 491-494. http://dx.doi.org/10.3748/ wjg.v9.i3.491

Kämmerer U, Kapp M, Gassel AM, Richter T, et al. (2001). A new rapid immunohistochemical staining technique using the EnVision antibody complex. J. Histochem. Cytochem. 49: 623-630. http://dx.doi.org/10.1177/002215540104900509

Kew MC, Dos Santos HA and Sherlock S (1971). Diagnosis of primary cancer of the liver. BMJ 4: 408-411. http://dx.doi. org/10.1136/bmj.4.5784.408

Kurokawa T, Miyamoto M, Kato K, Cho Y, et al. (2003). Overexpression of hypoxia-inducible-factor 1alpha(HIF-1alpha) in oesophageal squamous cell carcinoma correlates with lymph node metastasis and pathologic stage. Br. J. Cancer 89: 1042-1047. http://dx.doi.org/10.1038/sj.bjc.6601186

Liao D and Johnson RS (2007). Hypoxia: a key regulator of angiogenesis in cancer. Cancer Metastasis Rev. 26: 281-290. http://dx.doi.org/10.1007/s10555-007-9066-y

Maxwell PH, Dachs GU, Gleadle JM, Nicholls LG, et al. (1997). Hypoxia-inducible factor-1 modulates gene expression in solid tumors and influences both angiogenesis and tumor growth. Proc. Natl. Acad. Sci. USA 94: 8104-8109. http:// dx.doi.org/10.1073/pnas.94.15.8104

McGlynn KA and London WT (2005). Epidemiology and natural history of hepatocellular carcinoma. Best Pract. Res. Clin. Gastroenterol. 19: 3-23. http://dx.doi.org/10.1016/j.bpg.2004.10.004

Minet E, Michel G, Remacle J and Michiels C (2000). Role of HIF-1 as a transcription factor involved in embryonic development, cancer progression and apoptosis (review). Int. J. Mol. Med. 5: 253-259.

Parkin DM, Bray F, Ferlay J and Pisani P (2005). Global cancer statistics, 2002. CA Cancer J. Clin. 55: 74-108. http:// dx.doi.org/10.3322/canjclin.55.2.74

Rajaganeshan R, Prasad R, Guillou PJ, Scott N, et al. (2009). Expression patterns of hypoxic markers at the invasive margin of colorectal cancers and liver metastases. Eur. J. Surg. Oncol. 35: 1286-1294. http://dx.doi.org/10.1016/j. ejso.2009.05.008

Rankin EB and Giaccia AJ (2008). The role of hypoxia-inducible factors in tumorigenesis. Cell Death Differ. 15: 678-685. http://dx.doi.org/10.1038/cdd.2008.21

Salceda S and Caro J (1997). Hypoxia-inducible factor 1alpha (HIF-1alpha) protein is rapidly degraded by the ubiquitinproteasome system under normoxic conditions. Its stabilization by hypoxia depends on redox-induced changes. $J$. Biol. Chem. 272: 22642-22647. http://dx.doi.org/10.1074/jbc.272.36.22642

Semenza GL (2000). Hypoxia, clonal selection, and the role of HIF-1 in tumor progression. Crit. Rev. Biochem. Mol. Biol. 35: 71-103. http://dx.doi.org/10.1080/10409230091169186

Shibusa T, Shijubo N and Abe S (1998). Tumor angiogenesis and vascular endothelial growth factor expression in stage I lung adenocarcinoma. Clin. Cancer Res. 4: 1483-1487.

Talks KL, Turley H, Gatter KC, Maxwell PH, et al. (2000). The expression and distribution of the hypoxia-inducible factors HIF-1alpha and HIF-2alpha in normal human tissues, cancers, and tumor-associated macrophages. Am. J. Pathol. 157: 411-421. http://dx.doi.org/10.1016/S0002-9440(10)64554-3

Wang GL, Jiang BH, Rue EA and Semenza GL (1995). Hypoxia-inducible factor 1 is a basic-helix-loop-helix-PAS heterodimer regulated by cellular O2 tension. Proc. Natl. Acad. Sci. USA 92: 5510-5514. http://dx.doi.org/10.1073/ pnas. 92.12 .5510

Wang W, Xu GL, Jia WD, Wang ZH, et al. (2009). Expression and correlation of hypoxia-inducible factor-1alpha, vascular endothelial growth factor and microvessel density in experimental rat hepatocarcinogenesis. J. Int. Med. Res. 37: 417-425. http://dx.doi.org/10.1177/147323000903700217

Zagzag D, Zhong H, Scalzitti JM, Laughner E, et al. (2000). Expression of hypoxia-inducible factor 1alpha in brain tumors: association with angiogenesis, invasion, and progression. Cancer 88: 2606-2618. http://dx.doi.org/10.1002/10970142(20000601)88:11<2606::AID-CNCR25>3.0.CO;2-W

Zhong H, De Marzo AM, Laughner E, Lim M, et al. (1999). Overexpression of hypoxia-inducible factor 1alpha in common human cancers and their metastases. Cancer Res. 59: 5830-5835. 